\title{
Döviz Kuru Sanayi Üretimi ve Ekonomik Güven Arasındaki İlişkinin Analizi: Türkiye Örneği*
}

\author{
The Analysis of the Relationship Between Exchange Rate Industrial Production and Economic \\ Confidence: The Case of Turkey
}

\author{
İbrahim AYTEKİNa \\ a Doktora Öğrencisi, Kurıkkale \\ Üniversitesi Sosyal Bilimler Enstitüsü \\ İktisat Bölümü, Kırıkkale/Türkiye, \\ ibrahimaytekin63@gmail.com, \\ ORCID: 0000-0002-3574-1007
}

\section{ÖZ}

Döviz kurlarında yaşanan dalgalanmalar sanayisi ithal girdilere bağlı olan ülkeleri daha fazla etkilemektedir. Neticede ülkelerin sanayi üretimi ile döviz kurları birbirlerini etkileyen iki önemli faktör iken bu iki faktörün oluşturmuş olduğu iktisadi gelişmeler ekonomiye olan güveni de önemli derecede etkilemektedir. Bu çalışmada Türkiye'nin toplam sanayi üretimi, ekonomik güven endeksi ve reel döviz kuru göstergeleri arasında bir ilişkinin olup olmadığının tespit edilmesi hedeflenmiştir. Çalışmada Türkiye'nin 2008:M1-2020:M3 dönemlerine ait reel döviz kuru, toplam sanayi üretimi ile ekonomik güven endeksinin aylık verileri kullanılarak ekonometrik bir analiz yapılmıştır. Analizin ilk etabında değişkenlerin durağanlık derecelerini tespit etmek için değişkenlere genişletilmiş Dickey Fuller (ADF) testi uygulanmıș ve değișkenlerin tamamının birinci farkta durağan oldukları görülmüştür. Daha sonra bu değişkenlere Johansen eşbütünleşme testi uygulanmış ve değişkenler arasında uzun dönemli en az bir eşbütünleşme ilişkisinin olduğu sonucuna ulaşılmıştır. Son olarak değişkenlere Granger nedensellik testi uygulanmış ve üç değişken için tek yönlü bir Granger nedensellik ilişkisinin olduğu tespit edilmiştir. Nihayetinde reel döviz kuru, toplam sanayi üretimi ve ekonomik güven değişkenlerinin herhangi birinde veya hepsinde yaşanacak bir gelişmenin Türkiye ekonomisini iktisadi yönden etkileyebileceği sonucuna ulaşılmıştır.

Anahtar Kelimeler: Türkiye, Döviz, Sanayi, Üretim, Ekonomi, Güven.

\begin{abstract}
Fluctuations in exchange rates affect countries whose industries depend on imported inputs more. As a result, while the industrial production of countries and exchange rates are two important factors that affect each other, the economic developments caused by these two factors also significantly affect the confidence in the economy. The aim of this study is to determine whether there is a relationship among economic confidence index, total industrial production in Turkey and the real exchange rate indicators. An econometric analysis was conducted by using monthly data of economic confidence index, the total industry production and the real exchange rate belonging to period between 2008: M1 and 2020:M3 of Turkey. In the first stage of the analysis, the Augmented Dickey Fuller (ADF) test was applied to the variables to determine the degree of stationarity of the variables, and it was observed that all variables were stationary in the first difference. Then, Johansen cointegration test was applied to these variables and it was concluded that there is at least one longterm cointegration relationship between the variables. Finally, Granger causality test was applied to the variables and a one-way Granger causality relationship was found for three variables. Ultimately, a development that has occurred about one or all of the variables which are the real exchange rate, a total industrial production and the economic confidence could economically affect to the development of Turkey's economy.
\end{abstract}

Keywords: Turkey, Foreign Exchange, Industrial, Manufacturing, Economy, Trust.

\footnotetext{
* Bu makalede bilimsel araştırma ve yayın etiği ilkelerine uyulmuştur. / In this article, the principles of scientific research and publication ethics were followed.

Bu makale 26-27 Ağustos 2019 tarihinde Hoca Ahmet Yesevi Uluslararası Bilimsel Araştırmalar Kongresinde sunulan sözlü bildirinin düzeltilmiş ve genişletilmiş halidir.
} 


\section{GİRIŞ}

Sanayi devrimiyle birlikte hız kazanan Küreselleşme olgusu bu hızını Birinci Dünya Savaşı'na kadar sürdürmüştür. Birinci Dünya Savaşı Küreselleşmenin vites düşürmesine ve ülkelerin içe kapalı milliyetçi bir ekonomi politiğe yönelmelerine neden olmuştur. Yaşanan bu gelişmeler ise 1929 Krizinin (Büyük Buhran) patlak vermesine zemin hazırlamıştır. Milliyetçi ekonomi politiği ortadan kaldırarak uluslararası ticareti yeniden canlandırmak ve Dünya Savaşlarının etkilerini ortadan kaldırmak için yeni bir para sistemi olan Bretton Woods sisteminin oluşturulması, Gümrük Tarifeleri ve Ticaret Genel Anlaşması'nın (GATT) imzalanması, Dünya Bankası (WB) ve Uluslararası Para Fonu (IMF) gibi kurum ve sistemler kurulmuştur. Bu gelişmelerin yansımaları ise 1970'li yılların ortalarına kadar devam etmiştir.

1980’li yıllardan itibaren tekrar entegre olmaya başlayan ulusal piyasalar, iktisadi ve finansal küreselleşmenin önemli birer halkasını oluşturmaktadırlar. Özellikle ekonomik ve finansal alanda yaşanan liberalizasyon uluslararası ticareti hızlandırmış, sanayi üretimi ile döviz kurunu uluslararası ticaretin ayrılmaz birer parçası haline dönüştürmüştür. Böylece küreselleşen piyasalarda yaşanan bu gelişmeler günümüzde bir domino etkisi yaratmakta ve bu etki döviz kuru, ekonomik güven, sanayi üretimi, iktisadi büyüme, enflasyon, işsizlik gibi birçok iktisadi faaliyet ve göstergenin etkilenmesine neden olmaktadır. Bu bağlamda bu çalışmada, Türkiye'de döviz kuru, sanayi üretimi ve ekonomik güven arasındaki ilişkinin ekonometrik bir analizi yapılmıştır. Bu çalışmayı literatürdeki çalışmalardan ayıran özelliği Türkiye ekonomisine yönelik olarak seçilen analiz dönemin daha önce hiç çalışılmamış olması ve ayrıca seçilen konunun daha önce çok az çalışılmış olmasıdır. Özellikle de literatürde ekonomik güvene yönelik çalışmaların çok az olması bu çalışmayı literatür açısından diğer çalışmalardan önemli ve farklı k1lmaktadır.

\section{TEORIK ARKA PLAN}

\subsection{Döviz Kuru}

Bir ülkedeki yabancı paralara ve bu paralarla yapılan ödeme araçlarına döviz denilirken, yabancı paranın ulusal para cinsinden ifade edilmesine ise döviz kuru denilmektedir. Döviz kuru özelikle gelişmekte olan ülkelerin ekonomi politikalarını etkileyen uluslararası bir değişken olduğu için kurlarda meydan gelen dalgalanma veya şoklar ülkelerin makroekonomik göstergelerini etkileyebilmektedir. Bu bağlamda ihracatı ithal ara girdilere bağlı olan Türkiye gibi gelişmekte olan ülkelerde döviz kurularında meydana gelen şok ve dalgalanmalar ekonomide büyük etkiler yaratmaktadır (Tümtürk, 2017: 838). Bu etkiler, sanayi sektörünün üretim maliyeti ile kararlılığını etkilediği gibi ekonomik güven üzerinde de etkili olabilmektedir (Şentürk \& Dücan, 2014: 68).

Türkiye'de uygulanan döviz kuru sistemi yıllara göre farklılık göstermektedir. 1980 öncesi dönemde Türkiye'de sabit kur sistemi uygulanırken 1980 sonrası dönemlerde ise sabit kur sisteminden esnek kur sistemine bir geçiş süreci olmuştur. Bu süreçte 1980-1989 yılları arasındaki dönem ile 1989 yılında Türkiye'nin tam konvertibiliteye geçmesiyle birlikte başlayan 1989 sonrası dönem arasında farklılıklar vardır. Türkiye'de 1980-1989 dönemi devalüasyonların çokça yapıldığı sabit kur sistemi modelinin uygulandığı bir dönem olurken, 1989-1999 dönemi kontrollü serbest kur sisteminin uygulandığ bir dönem olmuştur. 2000-2001 döneminde ise artışların günlük olarak belirlendiği sabit kur sistemi modeli kullanılmıştır. 2001 yılının ortalarından günümüze kadar ise Türkiye Cumhuriyeti Merkez Bankası (TCMB) müdahalelerinin kısıtlandığı dalgalı kur sistemine geçilmiştir. Türkiye'de döviz kurlarının uluslararası ticarette bir avantaj araca olarak kullanıldığı 1980-2001 döneminde kısmen, 2001 sonrası dönemde ise tamamen ihracata dayalı iktisadi büyüme modeli kullanılmaktadır (Barışık \& Demircioğlu, 2006: 72).

\subsection{Sanayi Sektörü}

Sanayi kavramı köken olarak Arapça'ya dayanmaktadır. Fakat sanayi kavramı İngiliz James Watt'ın 1774 yılında buharlı makineleri icat etmesi ve bu makinelerin İngiltere sanayi sektöründe kullanılmaya başlanmasıyla birlikte Dünya gündemine oturmuştur. Kömürlü buhar gücüne dayanarak çalışan bu makineler, işbölümü, uzmanlaşma ve seri üretime ciddi katkılar sağlamıştır. Böylece dünyanın çehresini değiştiren ve birinci sanayi devrimi olarak adlandırılan bu gelişme, adını dünya ekonomi tarihine altın harflerle yazdırmıştır. Sanayi sektörü; imalat sanayi, madencilik, elektrik, su ve inşaat sektörlerini kapsayan geniş bir anlamda tanımlanmaktadır. Ayrıca sanayi sektörü, bir ülkenin tarım ve hizmetler sektörünü de önemli derece etkileyen bir güçtür. Tarım sektörü teknolojik gelişmelerden faydalanarak üretimi hızlandırmak ve maliyetleri düşürmek gibi hedeflerine ancak sanayinin gelişmesi sayesinde ulaşabilecektir. Günümüzde gelişmiş ekonomiler aynı zamanda sanayileşmiş ülkelerdir. Bu durum gelişmişliğin en önemli itici gücünün sanayi olduğunun en somut göstergesidir. Sanayi sektörü rekabet, teknoloji, içsel ve dışsal ölçek ekonomileri, nitelikli işgücü, altyapı ve üstyapı gibi kalkınmayı direkt etkileyen faktörleri tarım sektöründen daha fazla etkilemektedir. Dolayısıyla neredeyse tüm az gelişmiş ülkelerde sanayileşme, iktisadi kalkınmanın temel politikası olarak kabul edilmiştir. Son olarak da sanayileşme, sosyal ve kültürel yapıda da ciddi değişimler yaratmaktadır (Koç \& vd., 2018: 2-3).

Türkiye'de uygulanmakta olan kalkınma planlarında sanayileşme ve kalkınma hedefleri ise aynı amaç doğrultusunda entegre edilmiştir. Özellikle 1980 sonrası dönemlerde hayata geçirilen kalkınma ve dış ticarette liberalleşme politikalarıyla gayri safi milli hasıla ve uluslararası ticarette sanayi sektörünün payının arttırılması hedeflenmiştir. Türk sanayi sektörünün gelişimini zorunlu hale getiren birden fazla sebep vardır. Evvela emeğin yoğun olduğu sanayi sektörlerinde yaşanacak olumlu bir gelişme istihdam yaratma hedeflerine ciddi katkılar sağlayabilir. Güney Kore ve Tayvan gibi gelişmiş ve gelişmekte olan birkaç ülke bu tecrübeyi yaşamıştır. Aynı zamanda nüfus artış hızının yüksek olduğu ve genç bir nüfus yapısına sahip olan Türkiye'de tarım sektörünün istihdam yaratma alanında yetersiz oluşu Türkiye'de işsizlikten kaçınmada sanayileşme politikalarını alternatifsiz bırakmıştır. Ayrıca tarım sektöründeki istihdamın mevsimsel etkilerden olumsuz bir şekilde etkilenmesi işgücü ve istihdam 
istikrarsızlığının ortadan kaldırılması için Türkiye'de sanayi sektörünün geliştirilmesini zorunlu hale getirmiştir (Terzi \& Oltulular, 2004: 220).

\subsection{Ekonomik Güven Endeksi}

Ekonomik güven endeksi, ekonomideki arz ve talep yönündeki aktörlerin (üretici ve tüketicilerin), genel ekonomik duruma ilişkin davranış, değerlendirme, karar, beklenti ve eğilimlerini bir bütün olarak ve kapsamlı biçimde özetleyen ve öncü gösterge niteliğini taşıyan bir bileşik endekstir. Endeks, gayri safi yurt içi hâsıla (GSYH), istihdam ve sanayi üretim gibi yaygıı olarak kullanılan iktisadi göstergelerden daha erken bilgi sağlamakta ve mevcut iktisadi durumun izlenmesinin yanı sıra, ekonomideki kırılma noktaları ve potansiyel risklerin önceden görülerek tedbir alınmasını mümkün kılmak amacıyla kullanıma sunulmaktadır (TUİK, 2020: 1).

Ekonomik güven endeksi; tüketici güven endeksi (\%20), mevsimsel etkilerden arındırılmış reel kesim ve imalat sanayi sektörü (\%40), hizmet sektörü (\%30), perakende ticaret sektörü (\%5) ve inşaat sektörlerini (\%5) kapsayan güven endekslerinin normalize edilmiş alt endekslerinin ağırlık ortalamaları alınarak toplanmasından elde edilir. Ekonomik güven endeksi, Türkiye İstatistik Kurumu tarafından 2007 yılının ocak ayından itibaren her ayın sonunda olmak üzere aylık olarak yayımlanmaktadır. Ekonomik güven endeks değerinin 100'den büyük olması, ekonominin genel gidişatı hakkında iyimserliği ifade ederken; endeks değerinin 100'den küçük olması ise ekonominin genel gidişatı hakkında kötümserliği ifade etmektedir (Güngör, 2019: 25-26).

\section{LITERATÜR TARAMASI}

Literatürde, başta Türkiye olmak üzere birçok ülkeye yönelik; döviz kuru, sanayi üretimi, ekonomik güven ve tüketici güveni göstergelerini analiz eden birden fazla çalışma bulunmaktadır. Yapılan çalışmaların çoğunda elde edilen bulgular, döviz kuru, sanayi üretimi, ekonomik güven ile tüketici güveni arasında bir ilişkinin varlığı şeklindedir. Fakat literatürde azda olsa bu değişkenler arasında herhangi bir nedensellik veya eşbütünleşme ilişkisinin olmadığı sonuçlarına ulaşan çalışmalarda yer almaktadır. Bu tür sonuçların ortaya çıkmasındaki temel sebepler ise; ülkelerin gelişmişlik düzeylerinin farklı oluşu, çalışmalarda farklı dönem ve yöntemlerin kullanılmış olması, ülkelerin ulusal ve uluslararası konjonktürden farklı şekillerde etkilenmeleri şeklinde açıklanabilir. Bu doğrultuda yapılmış çalışmalara yönelik daha detaylı literatür sonuçları tablo 1'de verilmiştir.

Tablo 1. Literatür Tarama Tablosu

\begin{tabular}{|c|c|c|c|}
\hline $\begin{array}{c}\text { Yazar(lar) } \\
\text { (Yayın Yılı) }\end{array}$ & $\begin{array}{c}\text { Ülke(ler) } \\
\text { (Analiz Dönemi) }\end{array}$ & Yöntem & Bulgu ve Sonuç \\
\hline $\begin{array}{l}\text { Carlino, Gerald } \\
\text { vd. } \\
\text { (1994) }\end{array}$ & $\begin{array}{c}\text { ABD } \\
(1972-1989)\end{array}$ & $\begin{array}{l}\text { Kesitsel Zaman } \\
\text { Serisi }\end{array}$ & $\begin{array}{l}\text { Reel döviz kurundaki dalgalanmalar, yerli ve } \\
\text { yabancı üretim (toplam ve sektör bazında) } \\
\text { üzerinde küçük etkilerinin olduğu sonucuna } \\
\text { varılmıştır. Ayrıca devlet üretimindeki artışı } \\
\text { etkisi, döviz kuru dalgalanmalarındaki } \\
\text { etkiden daha fazla olduğu sonucuna } \\
\text { varılmıştır. }\end{array}$ \\
\hline $\begin{array}{l}\text { Görmüş, Şakir } \\
\text { \& } \\
\text { Güneş, Sevcan } \\
\text { (2010) }\end{array}$ & $\begin{array}{c}\text { Türkiye } \\
\text { (2002-2008) }\end{array}$ & $\begin{array}{l}\text { ARDL, Granger } \\
\text { Nedensellik Testi, } \\
\text { GARCH-M ve } \\
\text { OLS Modeli }\end{array}$ & $\begin{array}{l}\text { Değişkenler arasında bir eşbütünleşme ilişkisi } \\
\text { bulunmamıştır. Hisse senedi fiyatı ile reel } \\
\text { döviz kurundan tüketici güvenine doğru tek } \\
\text { yönlü bir nedensellik ilişkisi vardır. Ayrı, } \\
\text { GARCH-M ve OLS modelinden elde edilen } \\
\text { sonuçlar, tüketici güveninin reel döviz kurunu } \\
\text { ve hisse senedi fiyatını etkilediğini } \\
\text { göstermiştir. }\end{array}$ \\
\hline $\begin{array}{l}\text { Al-Rashidi Atef, } \\
\text { \& } \\
\text { Lahiri, Bidisha } \\
\text { (2012) }\end{array}$ & $\begin{array}{c}\text { ASEAN } \\
\text { +3 Ülke } \\
(1992-2004)\end{array}$ & Goldberg Metodu & $\begin{array}{l}\text { İhracat esaslı reel döviz kuru sanayi üretimini } \\
\text { artırdığını, fakat sanayi üretim seviyeleri } \\
\text { üzerinde önemli bir etkisinin bulunmadığı } \\
\text { sonucuna ulaşılmıştır. Ayrıca ithalatın ve } \\
\text { değer düşüklüğ̈unnun etkisinin reel döviz kuru } \\
\text { göstergelerine dahil edildiği durumlarda } \\
\text { simetrik olduğu bulunmuştur. }\end{array}$ \\
\hline $\begin{array}{l}\text { Arısoy İbrahim } \\
\text { (2012) }\end{array}$ & $\begin{array}{c}\text { Türkiye } \\
(2005-2012)\end{array}$ & VAR Modeli & $\begin{array}{l}\text { Tüketici güven endeksi tüketicilerin tüketim, } \\
\text { yatırımcıların ise yatırım ve üretim } \\
\text { beklentilerine yön vermektedir. }\end{array}$ \\
\hline $\begin{array}{l}\text { Jamil, } \\
\text { Muhammad } \\
\text { \& vd. } \\
(2012)\end{array}$ & $\begin{array}{c}\text { AB Parasal Birlik } \\
(1980-2009)\end{array}$ & $\begin{array}{c}\text { AR(k) } \\
\text { EGARCH(p,q) } \\
\text { Modelleri }\end{array}$ & $\begin{array}{l}\text { Ortak para biriminin yürürlüğe girmesinden } \\
\text { sonra tüm ülkeler için reel döviz kuru } \\
\text { oynaklığının olumsuz etkileri azalmıştır. }\end{array}$ \\
\hline $\begin{array}{l}\text { İbicioğlu, } \\
\text { Mustafa } \\
\text { \& vd. } \\
(2013)\end{array}$ & $\begin{array}{c}\text { Türkiye } \\
(2003-2011)\end{array}$ & $\begin{array}{l}\text { Johansen } \\
\text { Eşbütünleşme } \\
\text { ve } \\
\text { VAR Analizi }\end{array}$ & $\begin{array}{l}\text { Döviz kuru, tüketicilerin ekonominin } \\
\text { geleceğine yönelik beklentilerine ciddi yön } \\
\text { veren önemli faktörlerden biridir. }\end{array}$ \\
\hline
\end{tabular}




\begin{tabular}{|c|c|c|c|}
\hline $\begin{array}{c}\text { Uçan, Okyay } \\
\text { (2013) }\end{array}$ & $\begin{array}{c}\text { Türkiye } \\
(1990-2010)\end{array}$ & $\begin{array}{l}\text { Johansen } \\
\text { Eşbütünleşme } \\
\text { Testi }\end{array}$ & $\begin{array}{l}\text { Dışa açılma ve finansal liberilizasyon sonrası } \\
\text { döviz kurlarının belirlenmesinde dış piyasa ve } \\
\text { makroekonomik değişkenler etkili olurken, } \\
\text { merkezi otoritenin gücü zayıflamıştır. }\end{array}$ \\
\hline $\begin{array}{l}\text { Beşel, Furkan } \\
\& \\
\text { Yardımcıoğlu, } \\
\text { Fatih } \\
\text { (2016) }\end{array}$ & $\begin{array}{c}\text { Türkiye } \\
(2005-2014)\end{array}$ & $\begin{array}{c}\text { Zivot-Andrews } \\
\text { Gregory-Hansen } \\
\text { İle } \\
\text { Toda-Yamamoto } \\
\text { Nedensellik Testi }\end{array}$ & $\begin{array}{l}\text { Döviz kurundan işsizlik ile tüketici güven } \\
\text { endeksine doğru tek yönlü bir nedensellik } \\
\text { ilişkisi tespit edilmiştir. Ayrıca petrol } \\
\text { fiyatlarından işsizliğe doğru da tek yönlü bir } \\
\text { nedensellik ilişkisi bulunmuştur. Seriler } \\
\text { arasında eşbütünleşme ilişkisi de mevcuttur. }\end{array}$ \\
\hline $\begin{array}{c}\text { Laura, } \\
\text { Nowzohour } \\
\& \\
\text { Livio, Stracca } \\
\quad(2017)\end{array}$ & $\begin{array}{c}\text { Gelişmiş } \\
27 \text { Ülke } \\
(1985-2016)\end{array}$ & Panel Veri Analizi & $\begin{array}{l}\text { Tüketici güveni, iktisadi ve finansal } \\
\text { değişkenlerle birlikte hareket etmektedir. Bu } \\
\text { üç değişken arasında korelasyon ilişkisi } \\
\text { bulunurken, bu ilişki ileriye dönük pozitif } \\
\text { yöndedir. }\end{array}$ \\
\hline $\begin{array}{c}\text { Uçan, Okyay } \\
\& \\
\text { Aytekin, İbrahim } \\
\text { (2017) }\end{array}$ & $\begin{array}{c}\text { Türkiye } \\
(2004-2017)\end{array}$ & $\begin{array}{l}\text { Johansen } \\
\text { Eşbütünleşme } \\
\text { Testi }\end{array}$ & $\begin{array}{l}\text { Uzun dönemde eş bütünleşme ilişkisi tespit } \\
\text { edilmiştir. Ayrıca döviz kuru ile enflasyon } \\
\text { arasında aynı yönlü ilişkiye rastlanmıştır. }\end{array}$ \\
\hline $\begin{array}{l}\text { Bozkuş, Sezer } \\
\& \\
\text { Kahyaoğlu, } \\
\text { Hakan } \\
\text { (2018) }\end{array}$ & $\begin{array}{c}\text { Kazakistan } \\
(2002-2017)\end{array}$ & $\begin{array}{l}\text { Çok Kırılmalı } \\
\text { Tümleşme } \\
\text { Tekniği }\end{array}$ & $\begin{array}{l}\text { Reel efektif döviz kurları ile sanayi üretim } \\
\text { endeksi arasında harcama bakımından uzun } \\
\text { dönemli bir ilişki vardır. Bu ilişkinin bazı } \\
\text { dönemlerde tersine dönmesi sonucu Hollanda } \\
\text { hastalığıyla birlikte yaşandığ bulgusuna } \\
\text { ulaşılmıştır. }\end{array}$ \\
\hline $\begin{array}{l}\text { Ogunmuyiwa, M. } \\
\text { Segun } \\
\& \\
\text { Adelowokan, O. } \\
\text { Adedayo } \\
\text { (2018) }\end{array}$ & $\begin{array}{c}\text { Nijerya } \\
(1986-2016)\end{array}$ & $\begin{array}{l}\text { Box Jenkins } \\
\text { O.L.S Yöntemi ve } \\
\text { Chow Kırılma } \\
\text { Noktası Testi }\end{array}$ & $\begin{array}{l}\text { Ampirik bulgular, döviz kuru ve sanayi üretim } \\
\text { arasında uzun vadeli bir ilişkinin olmadığın } \\
\text { gösterse de, Box Jenkins O.L.S. sonuçları, } \\
\text { Nijerya'da döviz kurunun sanayi üretimi } \\
\text { üzerindeki olumlu ve önemli etkisini ortaya } \\
\text { koymaktadır. }\end{array}$ \\
\hline $\begin{array}{c}\text { Durgun Kaygisız, } \\
\text { Ayşe } \\
\text { (2019) }\end{array}$ & $\begin{array}{c}\text { Türkiye } \\
(2010-2018)\end{array}$ & VAR Analizi & $\begin{array}{l}\text { Döviz kurundaki dalgalanmaların enflasyon } \\
\text { ile tüketici güvenini etkilediği sonucuna } \\
\text { varılmıştır. Reel kesim güven endeksi, faiz ve } \\
\text { sanayi üretimi arasında ise çift yönlü } \\
\text { nedensellik ilişkisi bulunmuştur. }\end{array}$ \\
\hline $\begin{array}{c}\text { Güngör, Sezen } \\
\text { (2019) }\end{array}$ & $\begin{array}{c}\text { Türkiye } \\
(2007-2017)\end{array}$ & $\begin{array}{c}\text { Granger } \\
\text { Nedensellik Testi }\end{array}$ & $\begin{array}{l}\text { ABD doları ve altının reel getirilerinden } \\
\text { ekonomik güven endeksine doğru tek yönlü } \\
\text { bir nedensellik ilişkisi bulunmuştur. Buna } \\
\text { göre altının reel getirisi ile ABD dolarının reel } \\
\text { getirisi ekonomik güven endeksinin nedeni } \\
\text { şeklinde sonuçlara ulaş1lmıştır. }\end{array}$ \\
\hline $\begin{array}{l}\text { Petek, Ali } \\
\quad \& \\
\text { Şanl, Orhan } \\
\text { (2019) }\end{array}$ & $\begin{array}{c}\text { Türkiye } \\
(2007-2017)\end{array}$ & $\begin{array}{l}\text { Johansen } \\
\text { Eşbütünleşme ve } \\
\text { Granger } \\
\text { Nedensellik } \\
\text { Testi }\end{array}$ & $\begin{array}{l}\text { Kapasite kullanımından GSYİH ve sanayi } \\
\text { üretiminde doğru bir nedensellik ilişkisi tespit } \\
\text { edilmiştir. Ancak döviz kuru ile kapasite } \\
\text { kullanımı arasında bir nedensellik ilişkisi } \\
\text { bulunamamıştır. }\end{array}$ \\
\hline
\end{tabular}

\section{VERI SETİ ve YÖNTEM}

Reel döviz kuru, sanayi üretimi ve ekonomik güven değişkenleri arasındaki ilişkiyi Türkiye ekonomisi açısından inceleyen bu çalışmada yer alan veri setleri; reel döviz kuru, toplam sanayi üretimi ve ekonomik güven endeksinden oluşmaktadır. Analiz dönemi Türkiye'nin 2008:M1-2020:M3 y1lları arasındaki aylık verilerden oluşmaktadır. Veriler Türkiye Cumhuriyeti Merkez Bankası (TCMB) elektronik veri dağıtım sistemi ile Türkiye İstatistik Kurumu'ndan (TUİK) elde edilmiştir. Çalışmada verilerin logaritmik dönüşümleri yapılmış olup; LNRDK: Reel döviz kurunu, LNTSÜ: Toplam sanayi üretimini ve LNEKG: Ekonomik güveni ifade etmektedir. Analizlerde paket program kullanılmıştır.

Çalışmada ilk etapta değişkenlerin durağanlık durumu test edilmiştir. Akabinde tahmin edilecek Vektör Otoregresif (VAR) modeli için değişkenlerin uygun gecikme uzunluğu belirlenmiş ve bu doğrultuda tahmin edilen VAR modelinin tanısal testleri yapılmıştır. Tanısal testlerden sonra ise değişkenler arasında uzun dönemli bir ilişkinin olup olmadı̆̆ının tespiti için Johansen eşbütünleşme testi yapılmıştır. Daha sonra kısa dönemde meydana gelecek bir şok neticesinde modelin ne kadar sürede dengeye geleceğini gösteren hata düzeltme modeli tahmin edilmiştir. Analizde son olarak Granger nedensellik testi yapılarak değişkenler arasında bir nedensellik ilişkisinin olup olmadığı test edilmiştir. 


\section{AMPIRİK BULGULAR}

Zaman serileri analizlerinde ilk aşama değişkenlerin durağanlık durumlarının incelenmesinden oluşmaktadır. Eğer bir zaman serisinin ortalaması, varyansı ve otokovaryansı zamandan bağımsızsa bu zaman serisi durağan olarak kabul edilmektedir (Holden ve Perman, 1994: 49). Bu nedenle bu çalışmada ilk olarak analizde kullanılan değişkenlerin seviyede durağan olup olmadıklarının tespit edilmesi için değişkenlere düzey değerde Augmented Dickey-Fuller (ADF) birim kök testi uygulanmış ve sonuçlar tablo 2'de verilmiştir. Tablo 2'deki olasılık ve istatistiki değerlerde görüldüğü üzere; reel döviz kuru, toplam sanayi üretimi ve ekonomik güven değişkenlerinin düzey değerde durağan olmadıkları anlaşılmaktadır. Dolayısıyla düzey değerde durağan olmayan bu değişkenlerin birinci farklarına bakılmıştır.

Tablo 2. Düzey Değer Birim Kök Test Sonuçları

\begin{tabular}{|c|c|c|c|c|}
\hline \multirow{2}{*}{ Değişkenler } & \multicolumn{2}{|c|}{$\begin{array}{c}\text { Düzey Değer } \\
\text { (Sabit) }\end{array}$} & \multicolumn{2}{c|}{$\begin{array}{c}\text { Düzey Değer } \\
\text { (Sabit ve Trendli) }\end{array}$} \\
\cline { 2 - 5 } & $\begin{array}{c}\text { ADF t İstatistik } \\
\text { Değeri }\end{array}$ & Olas1lık Değeri & $\begin{array}{c}\text { ADF t İstatistik } \\
\text { Değeri }\end{array}$ & Olas1lik Değeri \\
\hline LNTSÜ & $-2.883^{*}$ & $0.110^{*}$ & $-3.444^{*}$ & $0.442^{*}$ \\
\hline LNRDK & $-2.882^{*}$ & $0.898^{*}$ & $-3.441^{*}$ & $0.369^{*}$ \\
\hline LNEKG & $-2.881^{*}$ & $0.187^{*}$ & $-3.441^{*}$ & $0.459^{*}$ \\
\hline
\end{tabular}

*: Olasılık(p) ve istatistik değerleri(t) $\% 1, \% 5$ ve \%10 önem seviyesinde anlamsızdır.

Düzey değerde durağan olmayan bu değişkenlere Augmented Dickey-Fuller (ADF) birim kök testi yeniden uygulanmıș ve değişkenlerin birinci farklarına bakılmıştır. Birinci farka göre elde edilen sonuçlar tablo 3 'te verilmiştir. Tablo 3 'teki olasılık ve istatistiki değerlerde görüldüğü üzere reel döviz kuru, ekonomik güven ve toplam sanayi üretimi değişkenlerinin birinci farkta durağan oldukları anlaşılmaktadır. Yani değişkenlerin tamamı I(1)'dir. Johansen (1988) ile Johansen ve Juselius (1990) tarafından geliştirilen modele göre değişkenler arasındaki eşbütünleşme ilişkisinin tespit edilebilmesi için değişkenlerin tamamının birinci farkta durağan yani I(1) olması gerekmektedir. Dolayısıyla bu çalışmada analize dahil edilen değişkenlerin tamamının I(1) olması değişkenlere Johansen eşbütünleşme testinin uygulanabileceğini göstermektedir.

Tablo 3. Birinci Fark Birim Kök Test Sonuçları

\begin{tabular}{|c|c|c|c|c|}
\hline \multirow{2}{*}{ Değişkenler } & \multicolumn{2}{|c|}{$\begin{array}{c}\text { Birinci Fark } \\
\text { (Sabit) }\end{array}$} & \multicolumn{2}{c|}{$\begin{array}{c}\text { Birinci Fark } \\
\text { (Sabit ve Trendli) }\end{array}$} \\
\cline { 2 - 5 } & $\begin{array}{c}\text { ADF t İstatistik } \\
\text { Değeri }\end{array}$ & Olasıllk Değeri & $\begin{array}{c}\text { ADF t İstatistik } \\
\text { Değeri }\end{array}$ & Olasılık Değeri \\
\hline LNTSÜ & $-2.883^{* *}$ & $0.000^{* *}$ & $-3.444^{* *}$ & $0.000^{* *}$ \\
\hline LNRDK & $-2.881^{* *}$ & $0.000^{* *}$ & $-3.441^{* *}$ & $0.000^{* *}$ \\
\hline LNEKG & $-2.881^{* *}$ & $0.000^{* *}$ & $-3.441^{* *}$ & $0.000^{* *}$ \\
\hline
\end{tabular}

**: Olasılık(p) ve istatistik değerleri(t) $\% 1, \% 5$ ve $\% 10$ önem seviyesinde anlamlıdır.

Değişkenlerin tamamının I(1) olduğu tespit edildikten sonra VAR modelinin kurulabilmesi için değişkenlerin uygun gecikme uzunlukları belirlenmiş ve gecikme uzunluğu sonuçları tablo 4'te verilmiştir. Serilerin gecikme uzunluklarının verildiği tablo 4'te yıldız (*) işaretinin en fazla yer aldığı satır en uygun gecikme uzunluğunu işaret eder. Bu bağlamda VAR tahmin modeli için uygun gecikme uzunluğu FPE, AIC LR, ve HQ kriterlerine göre 13 iken, SC kriterine göre 2'dir. Fakat; sağlıklı bir analiz için AIC kriterini kullanmak gerektiğinden analizlerde 13. gecikme uzunluğu seçilmiştir (Uçan \& Koçak, 2014: 57). Uygun bir VAR modelinin kurulabilmesi adına gecikme uzunluk sayısı yıllık değişkenler için 2 ya da 3, üçer aylık değişkenler için 3 ya da 4 ve son olarak aylık değişkenler için 12 ya da 13 olabilmektedir. Böylece bu çalışmada uygun VAR modelinin kurulabilmesi için tespit edilen 13. gecikme uzunluğu doğrultusunda VAR(13) tahmin modeli kurulmuştur (Mert \& Çağlar, 2019: 222).

Tablo 4. Gecikme Uzunluğu Sonuçları

\begin{tabular}{|c|c|c|c|c|c|c|}
\hline \multirow{2}{*}{ Gecikmeler } & \multicolumn{7}{|c|}{ Bilgi Kriterleri } \\
\cline { 2 - 6 } & LogL & LR & FPE & AIC & SC & HQ \\
\hline 1 & 691.438 & NA & 7.570 & -10.186 & -9.991 & -10.106 \\
\hline 2 & 719.011 & 52.677 & 5.740 & -10.463 & $-10.074 *$ & -10.305 \\
\hline 3 & 732.693 & 25.527 & 5.350 & -10.533 & -9.949 & -10.295 \\
\hline 4 & 742.528 & 17.907 & 5.290 & -10.545 & -9.767 & -10.229 \\
\hline 5 & 763.228 & 36.765 & 4.451 & -10.721 & -9.747 & -10.324 \\
\hline 6 & 778.099 & 25.747 & 4.081 & -10.807 & -9.640 & -10.333 \\
\hline 7 & 793.988 & 26.798 & 3.700 & -10.910 & -9.548 & -10.357 \\
\hline 8 & 803.249 & 15.204 & 3.700 & -10.914 & -9.357 & -10.281 \\
\hline 9 & 805.664 & 3.858 & 4.100 & -10.816 & -9.064 & -10.104 \\
\hline 10 & 814.068 & 13.045 & 4.161 & -10.806 & -8.860 & -10.016 \\
\hline 11 & 825.603 & 17.388 & 4.041 & -10.844 & -8.704 & -9.974 \\
\hline 12 & 880.867 & 80.833 & 2.041 & -11.535 & -9.110 & -10.586 \\
\hline 13 & 900.437 & $27.749^{*}$ & $1.770^{*}$ & $-11.693^{*}$ & -9.163 & $-10.665^{*}$ \\
\hline
\end{tabular}

* En uygun gecikme uzunluğunun kabul edildiğini gösterir. 
VAR(13) tahmin modeli oluşturulduktan sonra bu modelin durağan bir yapıya sahip olup olmadığının tespit edilmesi için modele Otoregresif Süreç (AR) karakteristik polinomu ters kök testi yapılmış ve test sonuçlarını gösteren birim çember şekil 1'de verilmiştir. Şekil 1'de görüldüğü üzere karakteristik köklerin tamamı çember içerisinde yer almaktadır. Karakteristik köklerinin tamamının çember içerisinde yer alması ise tahmin edilen VAR(13) modelinde durağanlık koşulunun sağlandığı ve bu durum analizlere devam edilebileceğini göstermektedir (Sağlam \& Egeli, 2014: 7).

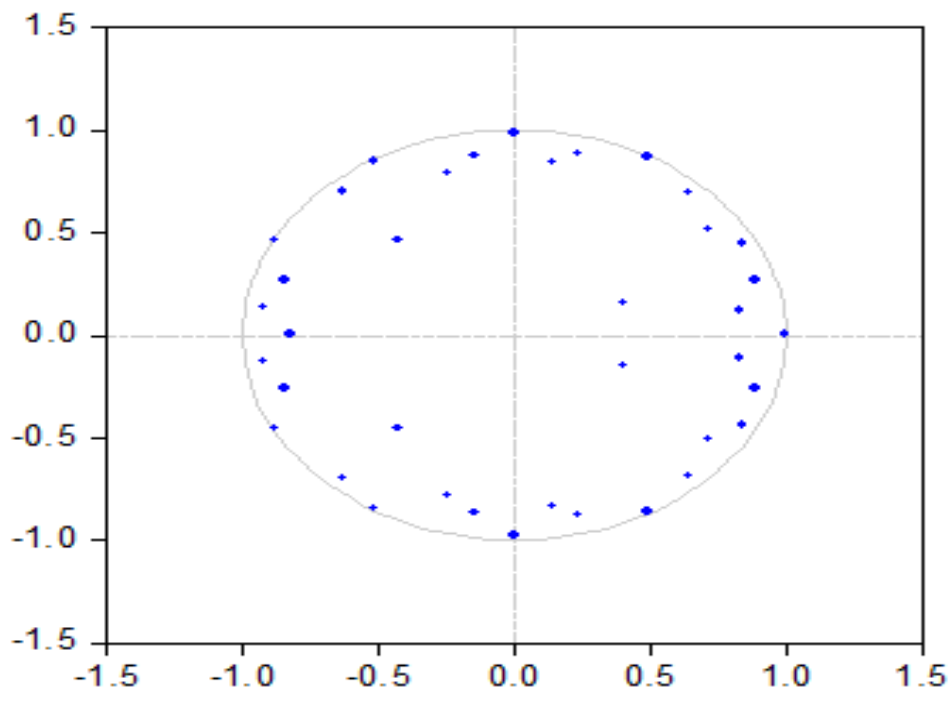

Şekil 1: AR Karakteristik Polinomunun Ters Kök Birim Çemberi

AR karakteristik polinomu testi sonuçlarına göre durağan olan VAR(13) modelinde ise bu sefer otokorelasyon ve değişen varyans sorununun olup olmadığının tespit edilmesi gerekmektedir. Bu doğrultuda oluşturulan VAR(13) modeline otokorelasyon LM testi ile White değişen varyans testleri uygulanmış ve uygulanan bu testlerin sonuçları tablo 5 'te verilmiştir. Tahmin edilen VAR(13) modelinin tablo 5'te görülen otokorelasyon LM testi sonuçlarına göre $\mathrm{P}=0.361>0.05$ olduğundan model için yokluk hipotezi reddedilememekte ve bu durum tahmin edilen VAR(13) modelinde otokorelasyon sorununun olmadığını göstermektedir. Aynı model için tablo 5'te verilen White değişen varyans test sonuçlarına göre de $\mathrm{P}=0.085>0.05$ olduğundan model için yokluk hipotezi reddedilememekte ve bu durum tahmin edilen VAR(13) modelinde değişen varyans sorununun olmadığını göstermektedir (Mert \& Çağlar, 2019: 226-229).

Tablo 5. Otokorelasyon LM ve White Değişen Varyans Test Sonuçları

\begin{tabular}{|c|cc|}
\hline \multicolumn{3}{|c|}{ Otokorelasyon LM Testi } \\
\hline Olasıllk Değeri (P) & 0.361 \\
\hline LM İstatistik Değeri & 9.867 \\
\hline \multicolumn{2}{|c|}{ White Değişen Varyans Testi } \\
\hline Olasılık Değeri (P) & 0.085 \\
\hline Ki-Kare $\left(X^{2}\right)$ & 510.461 \\
\hline
\end{tabular}

Tahmin edilen VAR(13) modelinde otokorelasyon ve değişen varyans sorununun olmadığı tespit edildikten sonra değişkenler arasında bir eşbütünleşme ilişkisinin olup olmadığının tespit edilmesi için modele Johansen eşbütünleşme testi uygulanmış ve bu sonuçlar tablo 6'da verilmiştir. Tablo 6'da verilen Johansen eşbütünleşme testi sonuçları değişkenler arasında uzun dönemde bir ilişkinin olup olmadığının incelenmesi için kullanılır. Bu bağlamda çalışmada 13 olarak tespit edilmiş olan uygun gecikme uzunluğunun 1 farkı alınarak 12 gecikme uzunluğu ile yapılan Johansen eşbütünleşme testi sonuçlarına göre; reel döviz kuru, toplam sanayi üretimi ve ekonomik güven arasında uzun dönemli en az bir eşbütünleşme ilişkisinin olduğu hem iz hem de maksimum özdeğer testleri tarafından onaylanmıştır.

Tablo 6. Johansen Eşbütünleşme Test Sonuçları

\begin{tabular}{|c|c|c|c|}
\hline İz Testi & \%5 Kritik Değeri & Olasılık Değeri(P) & Eş Bütünleşme Sayısı \\
\hline 65.147 & 29.797 & 0.000 & Hiç Yok* \\
\hline 6.681 & 15.495 & 0.615 & En Çok 1 Tane \\
\hline 2.033 & 3.841 & 0.154 & En Çok 2 Tane \\
\hline $\begin{array}{c}\text { Maksimum Özdeğer } \\
\text { İstatistiği }\end{array}$ & $\mathbf{\% 5 ~ K r i t i k ~ D e g ̆ e r i ~}$ & Olasılık Değeri & Eş Bütünleşme Sayısı \\
\hline 58.465 & 21.132 & 0.000 & Hiç Yok* \\
\hline 4.648 & 14.265 & 0.785 & En Çok 1 Tane \\
\hline 2.033 & 3.841 & 0.154 & En Çok 2 Tane \\
\hline
\end{tabular}

Johansen Eşbütünleşme Testi \%5 kritik değere göre yapılmıştır. 
Reel döviz kuru, toplam sanayi üretimi ve ekonomik güven arasında uzun dönemli bir ilişkinin tespit edilmesinden sonra kısa dönemde bu değişkenler arasındaki dengeden sapmanın ne kadar zaman sonra tekrar uzun dönem dengesine döneceği hata düzeltme modeli ile tespit edilmiştir. Bu bağlamda modelin çalışıp çalışmadığı ve uzun dönem dengesine ne kadar zamanda geldiğini gösteren hata düzletme modeli (HDM) sonuçları tablo 7'de verilmiştir. Tablo 7'de görüldüğü üzere hata düzletme terimi -0.279 değerini almış olup, hata düzeltme terimi negatif bir değer aldığı ve istatistiksel olarak anlamlı olduğu için hata düzeltme mekanizmasının çalıştığını göstermektedir. Burada, $1 /(|-0,279|)=3,6$ 'tür. Yani: döviz kuru, sanayi üretimi ve ekonomik güven değişkenleri arasında kısa dönemde meydana gelen dengesizlikler yaklaşık 4 aylık bir periyotta yeniden uzun dönem dengesine ulaşmaktadır.

Tablo 7. Hata Düzeltme Modeli(HDM) Test Sonuçları

\begin{tabular}{|c|c|c|c|}
\hline Hata Düzeltme & D(LNTSÜ) & D(LNRDK) & D(LNEKG) \\
\hline Hata Düzeltme Katsayıs1 & -0.279 & -0.146 & 0.247 \\
\hline Standart Hata & $(0.050)$ & $(0.052)$ & $(0.095)$ \\
\hline Hesaplanan t Değeri & {$[-5.588]$} & {$[-2.815]$} & [2.605] \\
\hline & & \multicolumn{2}{|c|}{ Normalize Edilmiş Denklem } \\
\hline & & \multicolumn{2}{|c|}{$\mathrm{LNEKG}=0.34 * \mathrm{LNRDK}+0.02 *$ LNTSÜ +2.963} \\
\hline \multicolumn{2}{|c|}{ Reel döviz kuru için hesaplanan $t$ değeri } & \multicolumn{2}{|c|}{$[-3.617]$} \\
\hline \multicolumn{2}{|c|}{ Sanayi üretimi için hesaplana t değeri } & \multicolumn{2}{|c|}{$[-0.244]$} \\
\hline
\end{tabular}

Ayrıca tablo 7'de normalize edilmiş denklem ile Türkiye'nin döviz kuru, sanayi üretimi ve ekonomik güven değişkenleri arasındaki uzun dönemli ilişki incelenmiştir. Elde edilen denkleme göre Türkiye'de uzun dönemde döviz kurunda görülen \%1'lik bir artış ekonomik güven üzerinde \%0.34'lük bir artış meydana getirirken, sanayi üretiminde görülen \%1'lik bir artış ise ekonomik güven üzerinde $\% 0.02$ 'lik bir artış meydana getirmektedir.

Son olarak değişkenler arasındaki ilişkinin yönünü tayin etmek için VAR(13) modeline Granger nedensellik testi uygulanmış ve elde edilen sonuçlar tablo 8'de verilmiştir. Burada eğer olasılık değeri \% 5 'ten küçük ise $\mathrm{H}_{0}$ hipotezi reddedilmekte ve Granger nedeni olarak kabul edilmektedir. Eğer olasılık değeri \% 5 'ten büyük ise $\mathrm{H}_{0}$ hipotezi kabul edilmekte ve Granger nedeni değil olarak tanımlanmaktadır.

Tablo 8. Granger Nedensellik Test Sonuçları

\begin{tabular}{|c|c|c|c|}
\hline & \multicolumn{3}{|c|}{ Bağımlı Değişken: LNTSÜ (Toplam Sanayi Üretimi) } \\
\hline Bağımsız Değişkenler & Ki Kare & Olasılık Değeri & Karar \\
\hline LNRDK & 53.348 & 0.000 & $\mathrm{H}_{0:} \mathrm{Red}$ \\
\hline LNEKG & 13.401 & 0.417 & $\mathrm{H}_{0: \mathrm{Kabul}}$ \\
\hline ALL & 78.506 & 0.000 & $\mathrm{H}_{0}:$ Red \\
\hline & \multicolumn{3}{|c|}{ Bağımlı Değişken: LNRDK (Reel Döviz Kuru) } \\
\hline Bağımsız Değişkenler & Ki Kare & Olasılık Değeri & Karar \\
\hline LNTSÜ & 15.321 & 0.288 & $\mathrm{H}_{0:}$ Kabul \\
\hline LNEKG & 22.152 & 0.053 & $\mathrm{H}_{0}:$ Kabul \\
\hline ALL & 36.568 & 0.082 & $\mathrm{H}_{0:}$ Kabul \\
\hline & \multicolumn{3}{|c|}{ Bağımlı Değişken: LNEKG (Ekonomik Güven) } \\
\hline Bağımsız Değişkenler & Ki Kare & Olasılık Değeri & Karar \\
\hline LNTSÜ & 50.841 & 0.000 & $\mathrm{H}_{0}: \mathrm{Red}$ \\
\hline LNRDK & 44.122 & 0.000 & $\mathrm{H}_{0:} \mathrm{Red}$ \\
\hline ALL & 100.002 & 0.000 & $\mathrm{H}_{0:}$ Red \\
\hline
\end{tabular}

- $\quad$ LNRDK $\rightarrow$ LNTSÜ’nün Granger nedenidir.

- $\quad$ LNEKG $\rightarrow$ LNTSÜ'nün Granger nedeni değildir.

- $\quad$ LNTSÜ $\rightarrow$ LNRDK'nin Granger nedeni değildir.

- $\quad$ LNEKG $\rightarrow$ LNRDK'nin Granger nedeni değildir.

- $\quad$ LNTSÜ $\rightarrow$ LNEKG'nin Granger nedenidir.

- $\quad$ LNRDK $\rightarrow$ LNEKG'nin Granger nedenidir.

Tablo 8'in ilk kısmında toplam sanayi üretimi (LNTSÜ) bağımlı değişken iken; reel döviz kuru (LNRDK) ve ekonomik güven (LNEKG) bağımsız değişkenlerdir. Analizde reel döviz kuru $(\mathrm{P}=0.00<0.05) \% 5$ önem seviyesinde anlamlı bulunurken, bir diğer bağımsız değişken ekonomik güven $(\mathrm{P}=0.417>0.05) \% 5$ önem seviyesinde anlamsız bulunmuştur. Bu bağlamda reel 
döviz kurundan toplam sanayi üretimine doğru bir nedensellik ilişkisinin olduğu, fakat ekonomik güvenden toplam sanayi üretimine doğru bir nedensellik ilişkisinin olmadığı tespit edilmiştir.

Tablo 8'in ikinci kısmında reel döviz kuru (LNRDK) bağımlı değişken iken; toplam sanayi üretimi (LNTSÜ) ve ekonomik güven (LNEKG) bağımsız değişkenlerdir. Analizde toplam sanayi üretimi $(\mathrm{P}=0.288>0.05)$ ve ekonomik güven $(\mathrm{P}=0.053>0.05)$ \%5 önem seviyesinde anlamsız bulunmuştur. Dolayısıyla toplam sanayi üretimi ile ekonomik güvenden reel döviz kuruna doğru herhangi bir nedensellik ilişkisinin olmadı̆̆ı tespit edilmiştir.

Tablo 8'in son kısmında ise ekonomik güven (LNEKG) bağımlı değişken iken; toplam sanayi üretimi (LNTSÜ) ve reel döviz kuru (LNRDK) bağımsız değişkenlerdir. Analizde reel döviz kuru ve toplam sanayi üretimi $(\mathrm{P}=0.00<0.059) \% 5$ önem seviyesinde anlamlı bulunmuştur. Bu bağlamda toplam sanayi üretimi ile reel döviz kurundan ekonomik güvene doğru bir nedensellik ilişkisinin olduğu tespit edilmiştir.

\section{SONUÇ VE DEĞERLENDİRME}

Türkiye gelişmekte olan ülkeler kategorisinde yer almaktadır. Türkiye ekonomisi dışa bağımlı bir yapıya sahip olduğu için küresel konjonktürde yaşanan iktisadi gelişmeler Türkiye ekonomisini etkileyebilmektedir. Özelliklede sanayisi ithal ara girdilere bağlı olan Türkiye'de yaşanan döviz kuru oynaklıkları Türkiye ekonomisini hem üretim hem de iktisadi güven açısından etkileyebilmektedir. Örneğin döviz kurlarında görülen bir artış; ithal ara girdilerden dolayı Türkiye'de sanayi üretimini olumsuz yönde etkileyebilirken, bu sebepten kaynaklı maliyet artışları ve üretimdeki daralmalar ise enflasyona neden olabilmektedir. Enflasyonla birlikte tüketicilerin alım gücü düşerken bu durum refah kayıplarına neden olmaktadır. Dolayısıyla üretimde yaşanan düşüşler, refah kayıpları ve enflasyon hanehalkının ekonomiye olan güvenini de etkileyebilmektedir. Bu nedenle bu çalışma Türkiye'de 2008 ile 2020 yılları arasında reel döviz kuru, toplam sanayi üretimi ve ekonomik güven endeksi arasında bir ilişkinin olup olmadığını ekonometrik bir yöntemle incelemektir.

Çalışmada Türkiye'de reel döviz kuru, toplam sanayi üretimi ve ekonomik güven değişkenlerinin uzun vadede birbirlerini etkileyen makroekonomik göstergeler oldukları sonucuna ulaşılmıştır. Bu bağlamda Türkiye'de uzun dönemde döviz kurunda görülen \%1'lik bir artış ekonomik güven üzerinde \%0.34'lük bir artış meydana getirirken, sanayi üretiminde görülen \%1'lik bir artış ise ekonomik güven üzerinde \%0.02'lik bir artış meydana getirmektedir. Ayrıca analizde kısa dönemde reel döviz kuru, toplam sanayi üretimi ve ekonomik güvende meydana gelen dengesizliklerin yaklaşık 4 aylık bir periyotta yeniden uzun dönem dengesine ulaşacağı gözlemlenmiştir. Son kertede Granger nedensellik ilişkisini değerlendirecek olursak; reel döviz kurlarından sanayi üretimine doğru kısa dönemli bir etki bulunurken, sanayi üretiminden reel döviz kurlarına doğru kısa dönemli bir etki bulunmamaktadır. Toplam sanayi üretiminden ekonomik güvene doğru ise kısa dönemli bir etki söz konusu iken, ekonomik güvenden toplam sanayi üretimine doğru kısa dönemli bir etki bulunmamaktadır. Son olarak reel döviz kurundan ekonomik güvene doğru kısa dönemli bir etki söz konusu iken, ekonomik güvenden reel döviz kurlarına doğru kısa dönemli bir etki bulunmamaktadir.

Nihayetinde döviz kuru, toplam sanayi üretimi ve ekonomik güven Türkiye ekonomisi için önemli makroekonomik değişkenlerdir. Elde edilen sonuçlara göre uzun vadede birbirlerini etkiyebilen bu değişkenlere yönelik olası bir şok veya şoklara karşı önleyici tedbirler almak gerekir. Bu durumda yapılabilecek en önemli şey döviz kuru dalgalanmalarını minimize edecek, sanayi üretiminin verim ile etkinliğini arttıracak ve ekonomiye olan güveni yükseltecek ekonomik, siyasi ve güvenlik politikalarını izlemektir. Bu politikalar neticesinde Türkiye’ye karşı iktisadi, siyasi ve güvenlik açısından oluşabilecek güçlü bir güven duygusu, Türkiye'ye daha fazla doğrudan ve dolaylı yabancı sermaye çekecektir. Neticede ekonominin dinamiklerini ve ekonomiye olan güven duygusunu her türlü gelişme ve şoklara karşı güçlü ve dirençli hale getirmek gerekiyor. Son olarak Türkiye ekonomisinde ithal ara girdilerde olan dışa bağımlılığı azaltmak, yerli ve iç piyasaya yönlendirici teşvik politikalarının daha fazla uygulanması gerekmektedir.

\section{KAYNAKÇA}

Al-Rashidi, A. \& Lahiri, B. (2012). Trade-Weighted Exchange Rate Indices: Explaining Industrial Production. Journal of International and Global Economic Studies. 5(2), 24-31.

Arısoy, İ. (2012). Türkiye Ekonomisinde İktisadi Güven Endeksleri ve Seçilmiş Makro Değişkenler Arasındaki İlişkilerin VAR Analizi. Maliye Dergisi, 162, 304-315.

Barışık, S. \& Elmas, D. (2006). Türkiye’de Döviz Kuru Rejimi Konvertibilete İhracat İthalat İlişkisi (1980-2001). Zonguldak Karaelmas Üniversitesi Sosyal Bilimler Dergisi, 2(3), 71-84.

Beşel, F. \& Yardımcıoğlu, F. (2016). Tüketici Güven Endeksi ile Makro Değişkenler Arasındaki İlişki. F. Savaşan \& vd. (Ed.) Uluslararası Politik, Ekonomik ve Sosyal Araştırmalar $\quad$ Kongresi Bildiriler Kitabı (s. 475-487 ). İstanbul.

Bozkuş, S. \& Kahyaoğlu, H. (2018). Üretim ile Reel Efektif Döviz Kurunun Uzun Dönemli İlişkisi: Kazakistan Üzerine Bir Uygulama. Ankara Hacı Bayram Veli Üniversitesi İktisadi ve İdari Bilimler Fakültesi Dergisi, 20(2), 360387.

Carlino, G. Voith, R. \& Brian, C. (1994). The Effects of Exchange Rate and Relative Productivity Changes on US Industrial Output at the State Level. Urban Studies, 31(2), 219-232. 
Durgun, Kaygısız, A. (2019). Türkiye'de Tüketici ve Reel Kesim Güven Endeksi ile Seçilmiş Makro Arasındaki İlişki: 2010-2018. Yönetim ve Ekonomi Araştırmaları Dergisi, 17(1), 314-332.

Görmüş, Ş. \& Güneş, S. (2010). Consumer Confidence Stock Prices and Exchange Rates: The Case Of Turkey. Applied Econometrics and International Development, 10(2), 103-114.

Granger, C. W.J. (1969). Investigating Causal Relations by Econometric Models and Cross- Spectral Methods. Econometrica, 37(3), 424-438.

Güngör, S. (2019). Ekonomik Güven Endeksi ve Finansal Yatırım Araçları Getirileri Arasındaki Nedensellik İlişkisi: 2007-2017 Döneminde ABD Doları ve Altın Getirileri Örneği. Yönetim ve Ekonomi Araştırmaları Dergisi, 17(1), 22-39.

Holden, D. \& Perman, R. (1994). Unit Roots and Cointegration for the Economist. B. B. Rao Applied Economist (s. 47-112). Palgrave Macmillan, New York.

İbicioğlu, M. Kapusuzoğlu, A. \& Karan, M. B. (2013). Türkiye'deki Tüketici Güven Endeksi ile Döviz Kuru Arasındaki İlişkinin Ampirik Analizi. İşletme Araştırmaları Dergisi 5(1), 5-16.

Jamil, M. Streissler, W. E. \& Kunst, M. R. ( 2012 ). Exchange Rate Volatility and its Impact on Industrial Production Before and After the Introduction of Common Currency in Europe. International Journal of Economics and Financial Issues. 2(2), 85-109.

Johansen, S. (1988). Statistical Analysis of Cointegration Vectors. Journal of Economic Dynamics and Control. 12, 231254.

Johansen, S. \& Juselius, K. (1990). Maximum Likelihood Estimated and İnference on Cointegration with Application to the Demand for Money. Oxford Bulletin of Economics and Statistics, 52(2), 169-210.

Koç, E. Şenel, M. C. \& Kaya, K. (2018). Dünyada ve Türkiye’de Sanayileşme I -Strateji ve Temel Sanayileşme Sorunlar1. Mühendis ve Makine Dergisi, 59(690), 1-26.

Mert, M. \& Çağlar, A. E. (2019). Eviews ve Gauss Uygulamalı Zaman Serileri Analizi. Ankara: Detay Yayıncılık.

Nowzohour, L. \& Stracca, L. (2017). More Than a Feeling: Confidence, Uncertainty and Macroeconomic Fluctuations. ECB Working Paper Series.

Ogunmuyiwa, M. S. \& Adelowokan, O. A. (2018). Measuring the Impact of Exchange Rate on Industrial Output in Nigeria. European Journal of Marketing and Economics, 1(2), 87-93.

Petek, A. \& Şanlı, O. (2019). Türkiye’de Gayrisafi Yurtiçi Hasıla, Döviz Kurları ve Sanayi ÜretimEndeksinin $\quad$ Kapasite Kullanım Oranları Üzerine Etkileri: Zaman Serileri Analizi. İnternational Review of Economics and Management. 7(1), 49-73.

Sağlam, Y. \& Egeli, H. A. (2014). Reel Döviz Kuru'nun Dış Ticaret Üzerine Etkisi ve Yoksullaştıran Büyüme: 2003-2013 Türkiye Örneği. S. Sarı \& vd. (Ed.) International Conference On Eurasian Economies Conference Book. (pp. 419427), Skopje/Macedonia.

Terzi, H. ve Oltulular, S. (2004). Türkiye'de Sanayileşme ve Ekonomik Büyüme Üniversitesi Dergisi. 5(2), 219-226.

Tümtürk, O. (2017). Türkiye’de Döviz Kurlarının Yurtiçi Fiyatlara Geçiş Etkisi ve Ekonomi Dergisi. 24(3), 837-855.

Türkiye Cumhuriyet Merkez Bankas1. (2020). Analiz verileri: 10.07.2020 tarihinde https://evds2.tcmb.gov.tr/, adresinden alındi.

$\begin{array}{llllll}\text { Türkiye İstatistik } \quad \text { Kururmu. } & \text { (2020), } & \text { Analiz } & \text { verileri: } & 10.07 .2020 \quad \text { tarihinde }\end{array}$ http://www.tuik.gov.tr/UstMenu.do?metod=temelist, adresinden alındı.

Türkiye İstatistik Kururmu. (2020), Ekonomik Güven Endeksi: $11.12 .2020 \quad$ tarihinde https://www.tuik.gov.tr/indir/revizyon/ege_metod_tr_2020.09.pdf, adresinden alınd1.

Şentürk, M. \& Dücan, E. (2014). Türkiye’de Döviz Kuru-Faiz Oranı ve Borsa Getirisi İlişkisi: Ampirik Bir Analiz. İşletme ve Ekonomi Araştırmaları Dergisi, 5(3), 67-80.

Uçan, O. (2013). Döviz Kuru Dinamikleri. Ankara: Seçkin Yayınevi

Uçan, O. \& Koçak, E. (2014). Türkiye'de Dış Ticaret ve Ekonomik Büyüme Arasındaki İlişki. Niğde Ömer Halisdemir Üniversitesi İIBF De 